\title{
СОВРЕМЕННЫЕ ИНФОРМАЦИОННЫЕ ТЕХНОЛОГИИ И ИХ ПРИМЕНЕНИЕ В СФЕРЕ ОБРАЗОВАНИЯ
}

\author{
Кривоногова A.E., Зарипова P.C.
}

Казанский государственный энергетический университет,

г. Казань, Российская Федерация

В статье рассматриваются ключевые тенденции развития информационных технологий в области образования, а также основныле аспекты внедрения инновачионных продуктов в сферу подготовки студентов, школьников и работников образования.

Ключевые слова: информационные технологии; образование; обучающие системы; учебный проиесс.

\section{MODERN INFORMATION TECHNOLOGIES AND THEIR APPLICATION IN THE FIELD OF EDUCATION}

\section{Krivonogova A.E., Zaripova R.S.}

Kazan state power university, Kazan, Russian Federation

The article discusses the key trends in the development of information technologies in the field of training and education, as well as the main aspects of introducing innovative products into the training of students, schoolchildren and educators.

Keywords: information technologies; education; learning systems.

В настоящее время развитие и распространение информационно-коммуникационных технологий (ИКТ) является важным приоритетом. ИКТ могут использоваться по-разному. Как ИКТ интегрируются в образовательные программы во многом зависит от учебных целей и стратегий учителей. Информация стала обильной 
и легкодоступной. Вместо того, чтобы читать унифицированную литературу, обычно представленную учебником, студенты получают доступ ко многим источникам информации. Вместо того, чтобы запоминать, студенты теперь учатся находить и выбирать соответствующую информацию для тех проблем, которые им необходимо решить. Им нужно научиться взаимодействовать с другими людьми, поскольку они решают эти проблемы и сообщают свои решения учителям и миру за пределами их класса. Вместо того, чтобы слушать лекции и запоминать факты, образовательные реформы показывают, что студенты учатся лучше всего в контексте решения сложных, реалистичных проблем. Традиционная компьютерная инструкция (CAI) и многие интегрированные обучающие системы (ILS) обеспечивают именно эту форму обучения целому ряду тематических областей. Обычно компьютеры, предназначенные для ILS, группируются в компьютерных лабораторных условиях, a не находятся лишь у учителей. Студенты, которые приобретают новую информацию по мере решения проблем, могут понять ее полезность, запомнить и использовать ее для решения проблем в будущем. Решение интересных проблем стимулирует интерес учащегося, чем запоминание отдельных фактов, и этот интерес, как было показано, положительно влияет на обучение. Студенты, решающие реальные проблемы, рассматривают свои усилия как настоящую работу, они имеют цель и мотивацию для дальнейшего развития. Учителя и преподаватели полагают, что ИКТ могут удовлетворить эти требования, и они интегрируют их в процесс обучения. ИКТ позволяют студентам непрерывно повышать уровень знаний. Например, онлайн-курсы, которые даже в отдаленных местах предоставляют студентам возможности для индивидуальных учебных курсов повышения квалификации. Эти курсы проводятся онлайн и предлагают синхронное взаимодействие между преподавателями и студентами. Они становятся очень популярными среди студентов заочной формы обучения, поскольку позволяют обучаться в любое время и из любого места. Компьютеры, ранее привязанные к определенному месту, быстро заменяются беспро- 
водными портативными компьютерами и смартфонами, которые позволяют студентам перемещаться по институту, собирать, делиться и обрабатывать данные быстрее, сообщать о результатах обучения учителям и родителям.

Мониторинг самостоятельного обучения студентов в этих гибких средах будет поддерживаться сложными новыми технологиями оценки, которые помогут учителям собирать и анализировать данные учащихся и принимать решения. Эти инструменты будут постоянно оценивать работу студентов и обеспечивать обратную связь с ними и их учителями. Хотя ИКТ создает возможности для фундаментальных изменений в том, как преподаватели учат, недавнее исследование показало, что только треть учителей чувствует себя готовым эффективно использовать их. ИКТ помогают учителям повысить свою производительность, готовить отчеты или планы уроков, делать заметки, беседовать с коллегами и родителями.

Эти базовые навыки необходимы, но недостаточны для создания изменений в обучении. Изменения требуют, чтобы учителя были знакомы с инструментами ИКТ и материалами по предметам, которым они учат. Они также должны иметь возможность включать эти ресурсы в классные занятия, которые выполняют важные учебные цели. Таким образом, внедрение в образование инновационных технологий не только делает процесс учебы проще, но и мотивирует учеников получать новые знания, помогает им своевременно получать информацию, не запоминая огромное количество информации, а также получать обучение дистанционно.

\section{Список литературы}

1. Зарипова Р.С. Особенности и тенденции развития современного инженерного образования / Р.С. Зарипова, О.А. Пырнова // Современные исследования социальных проблем. Красноярск: НаучноИнновационный Центр, 2018. Т.9. №8-2. С. 43-46.

2. Зарипова Р.С. Исследование влияния информационных технологий на формирование ценностных ориентаций современных студентов / 
Р.С. Зарипова, Н.Г. Бикеева // Современные исследования социальных проблем. 2018. Т. 9. № 7-2. С. 110-113.

3. Зарипова Р.С. Среды разработки программных приложений как составная часть информационных технологий в подготовке технических специалистов / P.C. Зарипова, Р.А. Ишмуратов // NovaUm.Ru. 2018. №11. С. 28-29.

4. Зарипова Р.С. Глобальные тренды современного образования // NovaUm.Ru. 2018. № 13. C. 232-234.

\section{References}

1. Zaripova R.S. Osobennosti i tendentsii razvitiya sovremennogo inzhenernogo obrazovaniya / R.S. Zaripova, O.A. Pyrnova // Sovremennye issledovaniya sotsial'nykh problem. Krasnoyarsk: Nauchno-Innovatsionnyy Tsentr, 2018. T.9. №8-2. S. 43-46.

2. Zaripova R.S. Issledovanie vliyaniya informatsionnykh tekhnologiy na formirovanie tsennostnykh orientatsiy sovremennykh studentov / R.S. Zaripova, N.G. Bikeeva // Sovremennye issledovaniya sotsial'nykh problem. 2018. T. 9. № 7-2. S. 110-113.

3. Zaripova R.S. Sredy razrabotki programmnykh prilozheniy kak sostavnaya chast' informatsionnykh tekhnologiy v podgotovke tekhnicheskikh spetsialistov / R.S. Zaripova, R.A. Ishmuratov // NovaUm.Ru. 2018. №11. S. 28-29.

4. Zaripova R.S. Global'nye trendy sovremennogo obrazovaniya // NovaUm. Ru. 2018. № 13. S. 232-234. 